\title{
The Effect of Treatment Ant Nest (Myrmecodia pendans) on Quail Production and Performance (Coturnix-coturnix japonica)
}

\author{
Susan Elfitri Lumban Gaol ${ }^{1 *}$, Edhy Sudjarwo ${ }^{2}$, Irfan Hadji Djunaidi ${ }^{2}$ \\ ${ }^{1}$ Master Program of Animal Husbandry, Faculty of Animal Husbandry, University of Brawijaya, Malang, Indonesia \\ ${ }^{2}$ Department of Animal Production Sciences, Faculty of Animal Husbandry, University of Brawijaya, Malang, Indonesia
}

\begin{abstract}
This research was aimed to determine the effect of ant nest treatment (Myrmecodia pendans) on quail production and performance. Research sample was 250 quails. Ant nest was administered in 5 treatments and 5 replications: $P_{0}(0 \%)$ as control treatment, $\mathrm{P}_{1}(0.2 \%), \mathrm{P}_{2}(0.4 \%), \mathrm{P}_{3}(0.6 \%)$, and $\mathrm{P}_{4}(0.8 \%)$ treatments. Data were collected from quails at 28 days to 70 days old. Variables measured were the performance and quail's egg production. This study was designed using completely randomized design. Real significant difference were examined utilizing Duncan's Multiple Range Test (DMRT). Analysis of variance result showed that ant nest provide significant influence to feed intake and Hen Day Production $(P<0.05)$. The highest average of feed consumption is treatment $P_{4}(0.8 \%)$, whereas treatment $P_{0}(0 \%)$ was the lowest average for feed consumption. Feed conversion rate in treatment $P_{4}(0.8 \%)$ was more efficient compared to other treatments. Ant nests administering did not result significantly different $(P>0.05)$ to feed conversion and egg mass. The results of the study concluded that higher ant nest administration is capable of increasing quails feed intake and Hen Day Production.
\end{abstract}

Keywords: basal feed, flavonoids, productivity.

\section{INTRODUCTION}

Quail farming is one of successful animal husbandry practices. Quail is one of efficient poultry. Their eggs and meat are food sources that contain high protein value [1]. Quail farm business is determined by three important aspects, i.e. breeding, feeding, and good management. This success is measured by optimally achieved profit rate. Expenditure on animal feed reached about $60-70 \%$ of total cost $[2,3]$. The type and amount of feed is related to the feed costs.

Feed cost increases with feed quality. Feed is one aspect which capable of affecting livestocks' performance, health and product quality $[4,5]$. In addition, providing quail feed supplement is one effort to improve quail production and performance. Unfortunately, farmers are dependent on antibiotics usage. Excessive use of antibiotics will cause negative impact due to quail resistance against microorganisms such as viruses, bacteria, fungi, rickettsiae, protozoa, [6]. Antibiotic residues in meat consumption can increase bacterial resistance to antibiotics, which would cause problems in animal and humans health [7]. Antibiotic usage as growth enhancers

\footnotetext{
* Correspondence author:

Susan Elfitri Lumban Gaol

Email : susanlgpruden@gmail.com

Address : Faculty of Animal Husbandry, University of Brawijaya, Veteran Malang, 65145
}

in poultry industry is prohibited, therefore alternative to antibiotics is required [8]. Alternatives were developed to find safer feed supplement ingredients. One effort that can be done to improve quail production and performance is by manipulating the feed ingredients containing natural antibiotics. Using local feed ingredients to replace factory made feed has not yet been recognized and used by quail breeders.

Traditional medicine is considered to have fewer side effects compared to chemical drugs [9], in addition to affordable price. Other advantages in using traditional medicine is easily available and relatively cheap raw material [10]. One of the medicinal plants that are beneficial to treat health disorders is ant nest (Myrmecodia pendans). Empirically, ant nest can cure variety of serious diseases such as tumors, cancer, heart disease, hemorrhoids, tuberculosis, rheumatism, uric acid disorders, stroke, ulcers, impaired renal function, and prostate [6]. Traditional drug in the Papua region is ant nest (Myrmecodia pendans).

Chemical test results demonstrated ant nest contains chemical compounds such as phenolic flavonoid [11]. Flavonoids are natural antioxidants capable of reducing hydroxyl radicals, superoxide and peroxyl radicals [12]. Therefore, we aim to examine Papuan ant nest (Myrmecodia pendans) application in quail feed on their egg-laying production performance 
which include feed comsuption, feed conversion ratio, hen day production and egg mass.

\section{MATERIALS AND METHODS \\ Subject}

Examined quail species is an Coturnix-coturnix japonica Autum strain (a crossbreeding between japonica pexigun) one Day Old Quail (DOQ). The quail type was eggs-laying quails. Research population was 250 quails. These were nursed starting from DOQ using ready-to-eat feed. Research treatment started at 28 days DOQ with basal feed. Ant nest was added in the form of flour and given at predetermined level (ANF = Ant Nest Flour). Statistical analysis used iscompletely randomized design. Data were examined using Duncan's Multiple Range Test (DMRT).

\section{Feed and Treatment}

Feed used as the control diet is feed prepared without the use of antibiotics. Feed ingredients used to formulate quail feed consist of yellow corn, soybean meal, MBM (meat bone meal) fish flour, pollard, dicalsium posfhat, premix, cooking oil, and Deglusa methionine. About $100 \mathrm{~kg}$ of feed were made using the feed ingredients (Table 1 and 2). Treatments were conducted as follows:

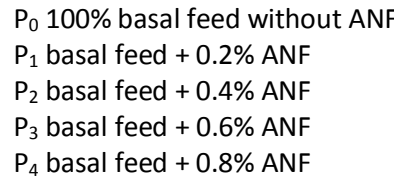

Extra ant nest flour administered in the feed, without changing quail feed requirements. Variables measured included feed consumption, feed conversion ratio, Hen day Productin (HDP) and Egg Mass. Ant Flour was added without necessarily changing feed demand of the quails.
Table 1. Active contents in ant (Myrmecodiapendans)

\begin{tabular}{lcc}
\hline \multicolumn{1}{c}{ Nutritional Value } & Unit & Value \\
\hline Energy (kg cal\%) & $\mathrm{Kcal} \cdot 100 \mathrm{~g}^{-1}$ & 350.52 \\
Carbohydrate & $\mathrm{g} \cdot 100 \mathrm{~g}^{-1}$ & 78.94 \\
Sodium (Na) & $\mathrm{mg} \cdot 100 \mathrm{~g}^{-1}$ & 68.58 \\
Tocopherol & $\mathrm{mg} \cdot 100 \mathrm{~g}^{-1}$ & 31.34 \\
Iron (Fe) & $\mathrm{mg} \cdot 100 \mathrm{~g}^{-1}$ & 29.24 \\
Ash & $\mathrm{g} \cdot 100 \mathrm{~g}^{-1}$ & 11,13 \\
Water & $\mathrm{g} \cdot 100^{-1} \cdot \mathrm{g}^{-1}$ & 4.54 \\
Potassium (K) & $\mathrm{g} \cdot 100 \mathrm{~g}^{-1}$ & 3.61 \\
Protein & $\mathrm{g} \cdot 100 \mathrm{~g}^{-1}$ & 2.75 \\
Fat & $\mathrm{g} \cdot 100^{-1} \cdot \mathrm{g}^{-1}$ & 2.64 \\
Magnesium (Mg) & $\mathrm{g} \cdot 100^{-1} \cdot \mathrm{g}^{-1}$ & 1.50 \\
Zinc (zn) & $\mathrm{mg} \cdot 100^{-1} \cdot \mathrm{g}^{-1}$ & 1.36 \\
Phosphorus (P) & $\mathrm{g} \cdot 100^{-1} \cdot \mathrm{g}^{-1}$ & 0.99 \\
Calcium (ca) & $\mathrm{g} \cdot 100 \cdot{ }^{-1} \mathrm{~g}^{-1}$ & 0.37 \\
Phenol & $\mathrm{g} \cdot 100^{-1} \cdot \mathrm{g}^{-1}$ & 0.25 \\
\hline Source: Subroto and Saputro $[13]$ &
\end{tabular}

Source: Subroto and Saputro [13]

Table 2. The Content of the Feed Nutrients Basal Value

\begin{tabular}{lc}
\hline \multicolumn{1}{c}{ Basal Feed Ingredients } & Value \\
\hline Gross Energy** & $3692.24 \mathrm{Kkal.kg}^{-1}$ \\
Crude Protein* & $21.90 \%$ \\
Fat** & $6.51 \%$ \\
Crude Fiber* & $3.18 \%$ \\
Calcium (ca)* & $2.55 \%$ \\
Phosphorus (P)* & $0.7 \%$ \\
Ash** & $15.36 \%$ \\
Dry Matter** & $86.47 \%$ \\
\hline
\end{tabular}

Source:

*Laboratory of Nutrition and Forage Department of Animal Husbandry and Fisheries Blitar.

**Laboratory and Nutrition Faculty Of Animal Husbandry Universitas Brawijaya.

\section{RESULTS AND DISCUSSION \\ Effect of Ant Nest to Quail Production and Performance}

Quail Production and Performance are exhibited in Table 3. Application in quail feed on the production performance include feed comsuption, feed conversion ratio, hen day production and egg mass.

Tabel 3. Quail Production and Performanceat 70 days DOQ

\begin{tabular}{|c|c|c|c|c|c|}
\hline Variable & $\mathbf{P}_{0}$ & $P_{1}$ & $\mathbf{P}_{2}$ & $\mathbf{P}_{3}$ & $\mathbf{P}_{4}$ \\
\hline Feed Consumption (g.bird ${ }^{-1}$ ) & $131.48 \pm 8.80^{b}$ & $141.85 \pm 8.70^{\mathrm{ab}}$ & $147.75 \pm 5.40^{\mathrm{a}}$ & $147.94 \pm 6.81^{\mathrm{a}}$ & $147.35 \pm 9.6^{a}$ \\
\hline Feed Convertion Ratio & $3.17 \pm 0.22$ & $3.14 \pm 0.14$ & $3.09 \pm 0.32$ & $3.05 \pm .0 .16$ & $3.00 \pm 0.14$ \\
\hline Hen Day Production (\%) & $56.11 \pm 2.64^{b}$ & $56.60 \pm 2.15^{b}$ & $58.16 \pm 2.93^{\mathrm{ab}}$ & $59.07 \pm 0.89^{a b}$ & $60.09 \pm 0.93^{\mathrm{a}}$ \\
\hline Egg mass (g) & $5.78 \pm 0.44$ & $5.67 \pm 0.27$ & $5.84 \pm 0.45$ & $5.85 \pm 0.35$ & $5.73 \pm 0.15$ \\
\hline
\end{tabular}

Description: $a, b$ different superscripts at same row indicate significant differences $(P<0.05)$

\section{Feed Consumption}

The effect of ant nest concentration addition to feed consumption are shown in Table 3. The results of analysis of variance indicates that increasing administering ant nest will increase quail feed intake $(P<0.05)$. Duncan test results showed that there are differences ant nest administering in treatment $P_{3}(0.6 \%)$ compared to $\mathrm{P}_{0}(0 \%)$ on the quail consumption.

Administering ant nest concentration in treatment $\mathrm{P}_{3}(0.6 \%)$ resulted similar effect with treatment $\mathrm{P}_{4}(0.8 \%), \mathrm{P}_{2}(0.4 \%)$ and $\mathrm{P}_{1}(0.2 \%)$. Average ant nest administering is apparent in treatment $\mathrm{P}_{3} \quad(0.6 \%)$ with highest average 
consumption. $P_{0}$ treatment (control) had the lowest average consumption.

The higher the concentration of ant nest administered, feed consumption will increase. This is caused by ant nest's flavonoid active compound content. Flavonoids possess antibacterial activity capable of killing pathogenic bacteria [14]. As a result, feed nutrition digestion and absorption process is not disturbed there by increasing the efficiency of feed nutrients. However, the results demonstrated a declined compared to $P_{3}$ and $P_{4}$. This is caused by certain restrictions. Flavonoids may reduce quail palatability, thus feed consumption will decline. Flavonoids are parts of phenolic compounds. Giving ant nest excessive levels lead to decreased levels of palatability quail, because of the bitter taste due to the high tannin content $[15,16,17]$ Flavonoids are a part of the phenolic compounds [18], suggesting a high phenol content causes the feed consumption is low and growth is slow [16]. Feed consumption extent depends heavily on the size of cattle, genetic properties (breed), ambient temperature, production rate, cage, feeding ground per animal,drinking water state, feed quality and quantity, and disease [19].

\section{Feed Convertion Ratio}

Feed conversion were shown in Table 3. Average ant nest administered to feed conversion in respective treatments were: $P_{0}$ were not administered the concentration. On the other hand, $P_{1}, P_{2}, P_{3}, P_{4}$ were administered ant nest in different level. Administering ant nest in treatment $\mathrm{P}_{4}(0.8 \%)$ showed lowest conversion average value. $P_{0}$ treatment (control) had highest conversion on quail.

Analysis of variance result showed that administering ant nest concentration was not significantly different to quail feed conversion ( $P>$ $0.05)$. It was reported that administering ant nest concentrations were also not significantly different to the feed conversion in broilers [20]. However, data generated by administering ant nest concentration showed a decrease in feed conversion. Ant nest administration tends to increase the feed efficiency to increase body weight. It is suspected that ant nest (Myrmecodia pendans) contains flavonoids active substances [21].

The results of this study indicate that lowest feed conversion was $P_{4}$ treatment with feed conversion at 3.00. Feed conversion value is used to determine the efficiency of feed usage. Higher value meant lower feed usage efficiency. Lower conversion value means better feed quality [22]. Previous research result showed quail feed conversion at 2.45 [23]. High feed conversion were obtained in this study because the examined quails are at beginning of productive age and have not yet reached peak production age.

Feed conversion is influenced by various factors, including feed quality, animal health and feeding procedures [24]. This indicates that diversity of feed types had no effect on feed conversion, because basically quail consumes feed material according to body nutritional needs. More feed material supplied does not affect conversion rate, but it is still efficient $[25,26]$. Feed material conversion rate can indicate efficiency level of feed material usage, greater conversion rate of feed material means less efficient feed material [27].

\section{Hen Day Production (HDP)}

The results of the analysis in Table 3 for average ant nest administering on Hen Day Production respectively are treatment $P_{0}$ were not administered ant nest concentration. $P_{1}, P_{2}$, $P_{3}$, and $P_{4}$ were given ant nest at different concentrations. Administering ant nest influenced Hen Day Production. $\mathrm{P}_{4}(0.8 \%)$ had highest average while $P_{0}$ (control) had lowest average.

Results of analysis of variance in Table 3 indicated that administering ant nest on Hen Day Production had a significant results $(P<0.05)$. Duncan test results indicated that administering ant nest concentrationin treatment $P_{4}(0.8 \%)$ had similar effect in $\mathrm{P}_{1}(0.2 \%), \mathrm{P}_{2}(0.4 \%)$, and $\mathrm{P}_{3}$ $(0.6 \%)$. The highest percentage of Hen Day Production is apparent in treatment $\mathrm{P}_{4}$ which is $60.09 \%$, while lowest percentage is $P_{0}(0 \%)$ for $56.11 \%$.

The higher the concentration of ant nest concentration improves Hen Day Production quail. Egg production is increased due to flavonoid compounds in ant nest [28]. The same research result is stated that the administration of antibiotics in poultry to promote growth, reduce disease, and produce a high egg production [29].

Flavonoid compound can disrupt cytoplasmic membrane functions of pathogenic bacteria cells in intestinal mucosa [30]. By that process, feed could increasenutrient absorption. Egg production rate is determined by feed consumption and protein content [31]. Increase in egg production rate is strongly influenced by protein 
content in the feed. This is in accordance with opinion that increase in energy content and protein can increase egg production rate, but has no effect on egg mass [32].

\section{Egg Mass}

The results of the analysis in Table 3 exhibited ant nest administration influence on egg mass in each treatment. $P_{3}$ treatment $(0.6 \%)$ had highest average. $P_{1}$ treatment had lowest egg mass average. In $\mathrm{P}_{3}$ treatment, it possessed high value caused by influence of flavonoid compound in ant nests which can increase nutrient absorption process. Therefore increasing egg production, while the $\mathrm{P}_{4}$ treatment did not affect the weight of the egg (egg mass), whereby the higher the flavonoid content causing palatability decreased as the effects of the bitter taste produced by compound anthill cause feed consumption also decreased so that the egg weight will decrease $[15,16]$.

Results of analysis of variance exhibited ant nest concentration administration was not significantly different $(P>0.05)$ on quail egg mass. The increase in weight of the egg (egg mass) is caused by the amount of protein produced by the consumption of quail. Influenced egg weight and egg albumin levels composed of protein, high intake of protein causes the protein in the feed is high [33]. It is also reported that increase in egg mass is influenced by quail protein consumption [34]. Protein is one of the necessary factors in egg formation in addition to calcium and phosphorus. Optimal quail egg production can be obtained should quail metabolism works well. Metabolic processes could either be achieved by meeting environmental and nutritional factors. Environmental factors include temperature and humidity [35].

\section{CONCLUSION}

Administering ant nest affect quail feed intake and Hen day production. Higher administered ant nest concentration will increase feed consumption and Hen day production. On the other hand, administering ant nest concentration does not affect feed conversion and egg mass.

\section{REFERENCES}

[1] Handarini, R., E. Saleh, B. Togatorop. 2008. Produksi burung puyuh yang diberi ransum dengan penambahan tepung umbut sawit fermentasi. Agri. Pet. 4. 107-110.

[2] Rusdi, U.D. 1992. Fermentation concentrates and cassava as well as the implications of its effect on the growth of broiler chickens. Dissertation. Program Study of Animal Husbandry, Padjadjaran University, Bandung.

[3] Sudrajat, S.D. 2000. Potential and prospects of local feed ingredients in developing the livestock industry in Indonesia. Paper. National Seminar on the Dies Natalis, Gadjah Mada University, Yogyakarta.

[4] Achmadi, J. 2007. Feed: the good quality and safe to support business success ranch. Tembalang Faculty of Animal Science, Diponegoro University, Semarang. Forage Quality Testing Center Directorate General of Livestock Ministry of Agriculture. 1-11.

[5] Subekti, E. 2009. Ketahanan pakan ternak Indonesia. 5(2). 63-71.

[6] Roslizawaty, N.Y. Ramadani, Fakhrurrazi. Herrialfian. 2013. Aktivitas antibakterial ekstrak etanol dan rebusan sarang semut (Myrmecodia sp.) terhadap bakteri Escherichia coli. Jurnal Medika Veterinaria. 7(2). 91-94.

[7] Phillips, I., M. Casewell, T. Cox, B. Groot, C. Friis, R. Jones, C. Nightingale, R. Preston, J. Waddell. 2004. Does the use of antibiotics in food animals pose a risk to human health. $J$. Antimicrob. Chemoth. 53. 28-52.

[8] Kannan, M., R. Karanakaran, V. Balakrishnan, T.G. Prabhakar. 2005. Influence of prebiotics supplementation on lipid profile of broilers. Int. J. Poult. Sci. 4(12). 994-997.

[9] Nur Iman, M. 2009. Anti-bacterial activity of methanol extracts male flowers papaya (Carica Papaya L) against Escherichia coli and Staphylococcus aureus multi-resistant antibiotic. Master Thesis. Faculty of Pharmacy, Surakarta Muhammadiyah University. Surakarta.

[10] Putri, Z.F. 2010. Antibacterial activity test on ethanol extract of piper leaves (Piper betle L.) to Propionibacterium acne and Staphylococcus aureus multi-resistant. Essay. Faculty of Pharmacy, Surakarta Muhammadiyah University. Surakarta.

[11] Daniel. 2010. Isolation of phenolic compounds in methanol-water fractions of tuber plants, ant nest (Myemecodia tuberose Jack). J. Chem. Mulawarman. 8. 1-6.

[12] Aaron, N., W. Syari. 2002. The antioxidant activity of leaf extract in inhibiting properties god hepatotoxic sub anesthetic halothane doses in mice. J. Pharm. Sci. Tech. 7. 63-70.

[13] Subroto, M.A., H. Saputro. 2006. Fight disease with ants nest. Swadaya. Jakarta. 1516. 
[14] Lima, B., M.B. Aguero, J. Zygaldo, A. Tapiai, C. Solis, A.R. De Arias, G. Yaluff, S. Zacchino, G.E. Feresin, G.S. Hirschman. 2009. Antimicrobial activity of extracts, essential oil and metabolites obtained from Tagetes mendocina. J. Chil. Chem. Soc. 54. 68-72.

[15] Ismarani. 2012. Tannin compounds in supporting potential production environmentally friendly. Cefars: J. Agribuss. Reg. Dev. 3(2). 46-55.

[16] Redondo, M., L. Pablo, A. Chacana, J.E. Dominguez, E. Mariano, M. Fernandez. 2014. Perspectives in the use of tannins as alternative to antimicrobial growth promoter factors in poultry. J. Front Microbiol. 5. 118. 1-7.

[17] Kusnadi, E. 2007. The efect of antanan (Centella Asiatica) administration as anti heat-stres agens in broilers diet containing hydrolized feather meal. Jurnal IImu Ternak. 7(1). 58-63.

[18] Alcorn, H. 2000. Plant, pest and predator: The ecological role of phenoilic. Available at: http://www.anci.cornella.edu/courses/as62/ 2000temp/phenolic.html.

[19] Suprijatna, E. 2005. The basic science of poultry. Penebar Swadaya. Jakarta.

[20] Yuanita, I., L. Silitonga, Paulini. 2014. Plant utilization ants nest (Myrmecodia pendans) as broiler feed additives. Indonesian J. Anim. Vet. Sci. 19(2). 138-142.

[21] Engidaa, A.M., N.S. Kasim, Y.A. Tsigie, S. Ismaji, L.H. Huynh, Y.H. Ju. 2013. Extraction, identification and quantitative HPLC analysis of flavonoids from sarang semut. (Myrmecodia Pendans). Ind. Crops Prod. 41. 392-396.

[22] Amrullah, I. K. 2003. Nutrisi ayam petelur. Lembaga Satu Gunung Budi. Bogor.

[23] Achmanu, Muharlien, Salaby. 2011. Influence of cage floor (meeting and tenuous) and male-female counterpart on consumption feed, weight eggs, feed conversion and thick egg shell in birds quail. Livest. Trop. 12. 1-14.

[24] Anggitasari, S., S. Osfar, H.D. Irfan. 2016. Effect of some kinds of commercial feed on quantitative and qualitative production performance of broiler chicken. Buletin Peternakan. 40(3). 187-196.

[25] Asiyah, N., D. Sunarti, Atmomarsono. 2013. The free choice feeding method to performace of Coturnix-coturnix japonica during 3-6 week old. Anim. Agr. J. 2(1). 497502.
[26] Gaol, S.E.L., L. Silitonga, I. Yuanita. 2015. Substitution of commercial feed with expired bread to performance of quails (Coturnix Coturnix Japonica) on starter to start pullet age. Jurnal Ilmu Hewani Tropika. 4(2). 61-65.

[27] Yunilas, B. Irawati, D.P.K. Tubagus. 2008. Pemanfaatan tepung kulit buah terong belanda (Cyphomandra Betacea) Fermentasi (Aspergillus Niger) terhadap produksi telur puyuh. J. Agribuss. 4(1).

[28] Huyghebaert, G., G. De Groote. 1997. The bioefficacy of Zinc Bacitracin in practical diets for broilers and laying hens. Poult. Sci. 76. 849-856.

[29] Donoghue, D.J. 2003. Antibiotic residues in poultry tissues and eggs: human health concerns. Poult. Sci. 82. 618-621.

[30] Suwandi, T. 2012. antibacterial potential development hibiscus flower petals Sabdariffa L (Roselle) against Streptococcus sanguinis inducers gingivitis towards standardized herbal medicines. Dissertation. Faculty of Dentistry, University of Indonesia. Depok.

[31] Triyanto. 2007. performance production Quail (Coturnix-coturnix japonica) production period age 6-13 sunday at old lighting layout. Essay. Animal Production Technology Studies Program. Faculty of Animal Husbandry. Bogor Agricultural University. Bogor.

[32] Sugandhi, D. 1973. The effect of different energy and protein level on the performance of laying hens in floor pens and cages in the tropics. Dissertation. Faculty of Animal Husbandry. Bogor Agricultural University. Bogor.

[33] Joseph, N. S., F.E. Robinson, D.R. Korver, R.A. Renema. 2000. Effect of dietary protein intake during the pullet-to-breeder transition period on early egg weight and production in broiler breeders. Poult. Sci. 79. 1790-1796.

[34] Maknun, L., S. Kismiati, I. Mangisah. 2015. Performans produksi burung puyuh (Coturnixcoturnix japonica) dengan perlakuan tepung limbah penetasan telur puyuh 25(3). 53-58.

[35] Kurnia, S.D., K. Praseno, Kasiyati. 2012. Egg Yolk Index (IKT) and Haugh Unit (Hu) quail eggs maintenance results with combination solution providing micromineral ( $\mathrm{Fe}, \mathrm{Co}, \mathrm{Cu}$, $\mathrm{Zn})$ and vitamins (A, B1, B12, C) as drinking water. Anat. Physiol. Bull. 20 (2). 24-31. 